\title{
Reducing the Pollutants from Municipal Wastewater by Chlorella Vulgaris Microalgae
}

\author{
Massara Mustafa Hammad* \\ Hussein A. Sabti*** \\ *,** Department of Biochemical Engineering/Al-Khwarizmi College of Engineering/University of Baghdad \\ *** Office of Research and Technology of Environment and Water/ Ministry of Science and Technology \\ *Email: m_massara@yahoo.com \\ **Email:kwhameed74@yahoo.com \\ *** Email:sabtie_59@yahoo.com
}

(Received 1 July 2018; accepted 24 September 2018)

https://doi.org/10.22153/kej.2019.09.001

\begin{abstract}
In the present work, the pollutants of the municipal wastewater are reduced using Chlorella vulgaris microalgae. The pollutants that were treated are: Total organic carbon (TOC), Chemical oxygen demand (COD), Nitrate $\left(\mathrm{NO}_{3}\right)$, and Phosphate $\left(\mathrm{PO}_{4}\right)$. Firstly, the treatment was achieved at atmospheric conditions (Temperature $=25^{\circ} \mathrm{C}$ ), $\mathrm{pH} 7 \mathrm{with}$ time $(1-48 \mathrm{~h})$. To study the effect of other microorganisms on the reduction of pollutants, sterilized wastewater and unsterilized wastewater were used for two types of packing (cylindrical plastic and cubic polystyrene) as well as algae's broth (without packing), where the microalgae are grown on the packing then transported to the wastewater for treatment. The results showed that the other microorganism in unsterilized wastewater can slightly contribute in the treatment. Packing of cylindrical plastic is more effective than the cubic polystyrene, and microalgae's broth gives better results than the two types of packing. The treatment in the first hours was performed quickly while in the last hours, it was very slow. Then, the following parameters in the range of (temperature: $\left.20-35^{\circ}\right) \mathrm{pH}(5-8)$, volume ratio of wastewater to microalgae's broth $(1-2.5)$ were studied for sterilized wastewater and constant treatment time equal to $48 \mathrm{~h}$. The results showed that the maximum reduction of pollutants are: $\mathrm{TOC}=92.3 \%, \mathrm{NO}_{3}=65.2 \%, \mathrm{PO}_{4}=93.2 \%$ at $\mathrm{T}$ $=35^{\circ} \mathrm{C}, \mathrm{pH} 8$, and (wastewater/algae broth) ratio $=1$, and $\mathrm{COD}=85.6 \%$ at $\mathrm{T}=30^{\circ} \mathrm{C}, \mathrm{pH} 7$, and (wastewater/ algae broth) ratio $=1$. The temperature and $\mathrm{pH}$ have little effect on the reduction of pollutants compared with the wastewater/algae broth ratio. The adsorption isotherm for pollutant was also studied for three types of isotherm; linear, Freundlich, and Langmuir. The results showed that the treated pollutants are the Langmiur adsorption isotherm.
\end{abstract}

Keywords: Biofiltration, microalgae, treatment, Wastewater.

\section{Introduction}

The municipal wastewater have many pollutants such as nitrate, phosphorus, $\mathrm{CO}_{2}$, TOC, etc of the organic and inorganic pollutants that cause increasing in the BOD, COD which harm the environment dramatically $[1,2]$. So it is necessary to treat the pollutants in wastewater before discharge to the river. There are many methods to treat the pollutants in wastewater named physical treatment such as screening, sedimentation, precipitation, aeration, filtration, ...etc, chemical treatment such as chlorination, ozonation, coagulation, ion exchange, ...etc, and biological treatment such as activated sludge treatment methods, trickling filtration, oxidation ponds, lagoons, anaerobic digestion, septic tanks, etc [3]. Present of pollutant in the water bodies on one hand aggravates the phenomena such as algal flowers and on the other hand influents the ecological balance of water and subsequently decays the water characteristic [4]. Microalgae are widely used as a multi-biotreatment process to reduce nitrogen and phosphorus from wastewater since they require nitrogen, phosphorus, $\mathrm{CO} 2$, and 
light for their autotrophic metabolic growth $[5,6]$. The process of microalgae is an effective and little technology process which offers inveterate cost savings and provides a more suitable method of water treatment for improving countries [7]. One of the main features of algal processes over classical treatment is the ability to recycle the nutrients forming rich value products, such fertilizers, medicinal products, food additives and biofuels $[8,9,10]$. Chlorrela vulgaris is a unicellular microalgae present individually or in flocks that consume carbon dioxide, nitrogen, and phosphorous and release oxygen [11]. The main objectives of the present work are to reduce the pollutants from wastewater at optimum operating conditions.

\section{Experimental Procedure}

\subsection{Materials}

- Wastewater: It is taken from municipal of Baghdad-Aljaderia.

- Chlorrela Vulgaris microalgae: It is obtained from Ministry of science and technology/ Office of Research and technology of environment and water.

- Packing: Two type of packing are used; Cylindrical plastic (polyethylene-glycol, PVC) with dimensions: length $=1 \mathrm{~cm}$, diameter $=0.8$ $\mathrm{cm}$, thickness $=0.1 \mathrm{~cm}$ and has specific surface area $=261 \mathrm{~m}^{2} / \mathrm{m}^{3}$.

Cubic polystyrene: Its dimensions are $1 \times 1 \times 1$ $\mathrm{cm}$ and has specific surface area $=180 \mathrm{~m}^{2} / \mathrm{m}^{3}$.

- BG-11 Media: It is composed of $(\mathrm{g} / \mathrm{l}): \mathrm{NaNO}_{3}$ 150, $\mathrm{K}_{2} \mathrm{HPO}_{4} \quad 4.0, \quad \mathrm{MgSO}_{4} .7 \mathrm{H}_{2} \mathrm{O} \quad 7.5$, $\mathrm{CaCl}_{2} .2 \mathrm{H}_{2} \mathrm{O}$ 3.6. Citric acid 0.6, Ferric citrate 0.6, EDTA-Na 0.1, $\quad \mathrm{Na}_{2} \mathrm{CO}_{3} \quad 2.0$, and Micronutrient solution 0.532 . The source of this media is HIMEDIA, India. It is support the growth of microalgae.

\subsection{Experimental Procedure}

Cultivation media is prepared by suspension $1.627 \mathrm{~g}$ of BG-11 per liter of distilled water then autoclaved at $121^{\circ} \mathrm{C}$ for $20 \mathrm{~min}$. After cooling the prepared media solution to the room temperature, add $250 \mathrm{ml}$ of solution into flasks each capacity $500 \mathrm{ml}$. The isolated microalgae are cultured in each flask, the flasks are stoppered by cotton, aerated by $0.5 \mathrm{lit} / \mathrm{min}$ sterilized filtered air (through milipore filter $0.25 \mu \mathrm{m}$ ) and exposure to neon light intensity of 2500-2600 lux measured by (Photometer milkwaukee, China). The temperature is maintained at $25^{\circ} \mathrm{C}$ by kept the flasks in incubator [12]. The growth period of microalgae is 7 days. The broth solution now is ready to use in the treatment.

Wastewater is filtered by filter paper and sterilized at $121^{\circ} \mathrm{C}$ for $20 \mathrm{~min}$ to ensure there is no microorganisms are present and the microalgae will be alone that used in the treatment. The columns with capacity of $500 \mathrm{ml}$ are used for treatment where $250 \mathrm{ml}$ of wastewater added to the columns and $250 \mathrm{ml}$ of microalgae broth are added to the wastewater where the ratio of wastewater/algae broth becomes 1 . The $\mathrm{pH}$ of the contents is adjusted to 7 . The columns are stoppered from one end with teflon and the other end with cotton. The columns are aerated by 0.5 lit/min filtered air and exposure to neon light intensity of 2500-2600 lux. The temperature is maintained at $25^{\circ} \mathrm{C}$ by kept the columns in incubator. The samples $(5 \mathrm{ml})$ are taken with time for analyses and measure the pollutants.

Figure 1 shows the process flow diagram of the wastewater treatment by microalgae.

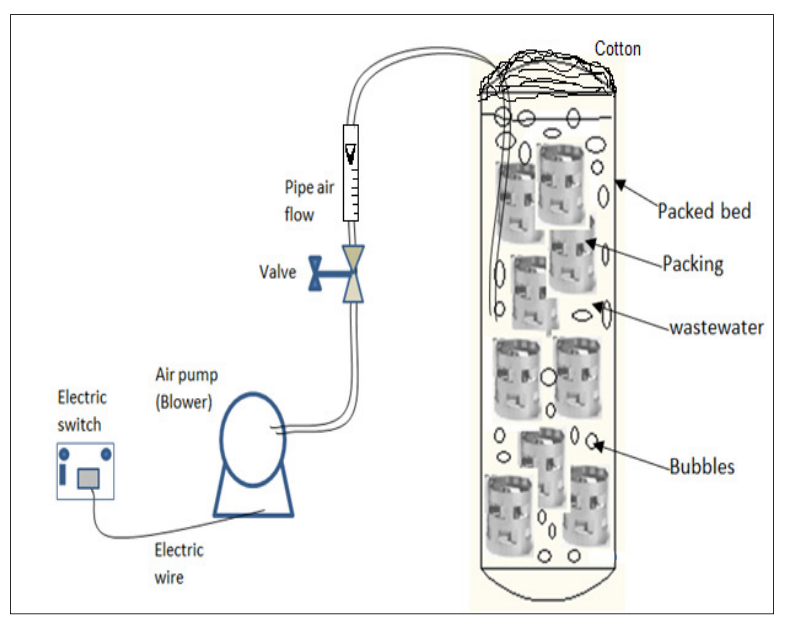

Fig. 1. Process flow diagram of the wastewater treatment by microalgae.

Table 1 shows the method of measurement of the pollutants.

Table 1,

The method of measurement of the pollutants

\begin{tabular}{ll}
\hline Pollutants (mg/l) & Measurement method \\
\hline TOC & UV light and a digesting \\
& reagent, sodium persulphate \\
$\mathrm{COD}$ & UV-VIS Spectroscopy \\
$\mathrm{NO}_{3}$ & UV-Spectrophotometer \\
$\mathrm{PO}_{4}$ & UV-Spectrophotometer \\
\hline
\end{tabular}




\section{Results and Discussion}

\subsection{Time Effect}

Figures $1-4$ show the concentration of the pollutants TOC, $\mathrm{COD}, \mathrm{NO}_{3}$, and $\mathrm{PO}_{4}$ with time at temperature of $25^{\circ} \mathrm{C}, \mathrm{pH} 7$, wastewater/(Algae broth) volume ratio $=1$, and sterilized wastewater. The wastewater is sterilized in autoclave at $121^{\circ} \mathrm{C}$ for $20 \mathrm{~min}$ to eliminate from any microorganism can contribute in treatment and microalgae will evaluated individually as remediation tool.

It can be seen from figures $1-4$ that the pollutants are decreased rapidly in the first hours then decreased slowly with progress of time. The experimental operation time is stopped at $48 \mathrm{~h}$ because the decreasing of pollutants becomes very slowly.

Figure 5 shows the removal percent of pollutants with time at temperature of $25^{\circ} \mathrm{C}, \mathrm{pH}$, wastewater/(Algae broth) volume ratio $=1$, and sterilized wastewater. It can be seen that the maximum removal percent of TOC $=87 \%, \mathrm{PO}_{4}=$ $86 \%, \mathrm{COD}=78 \%$, and $\mathrm{NO}_{3}=50.7 \%$ after $48 \mathrm{~h}$.

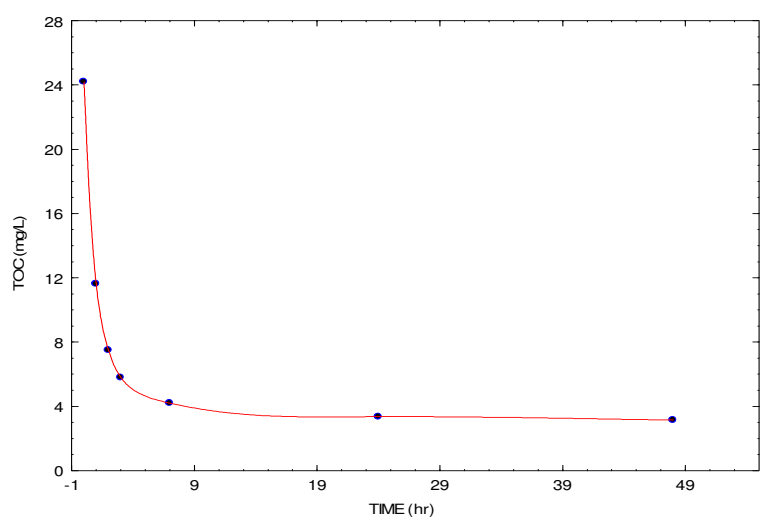

Fig. 1. TOC Pollutant concentration with time at $T=$ $25^{\circ} \mathrm{C}, \mathrm{pH} 7$, wastewater/(Algae broth) ratio $=1$, and sterilized wastewater.

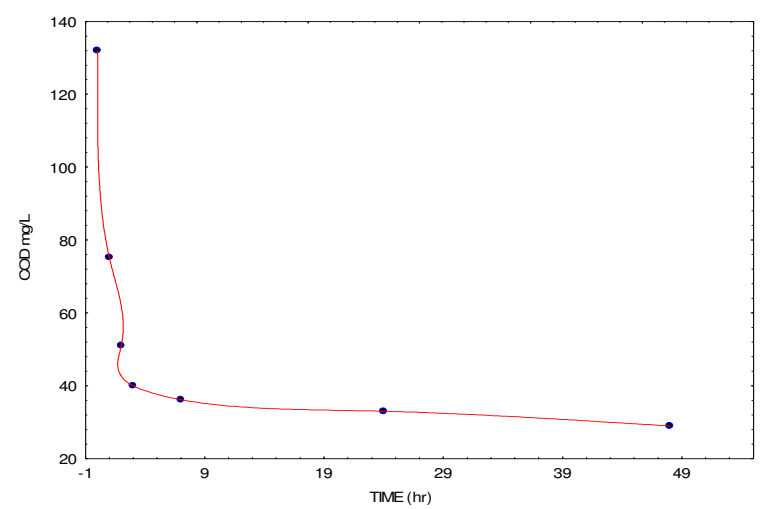

Fig. 2. COD Pollutant concentration with time at $\mathrm{T}=2^{\circ} \mathrm{C}, \mathrm{pH} 7$, wastewater/(Algae broth) ratio $=1$, and sterilized wastewater.

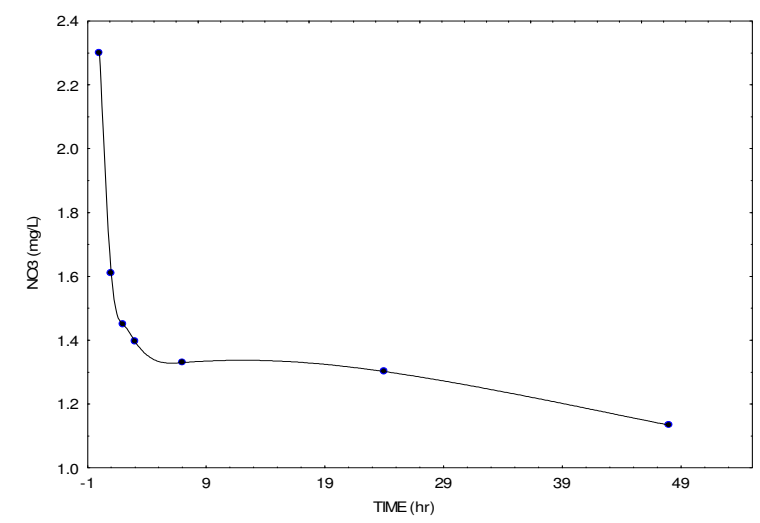

Fig. 3. $\mathrm{NO}_{3}$ Pollutant concentration with time at $\mathbf{T}=$ $2^{\circ} \mathrm{C}$, $\mathrm{pH} 7$, wastewater/(Algae broth) ratio $=1$, and sterilized wastewater.

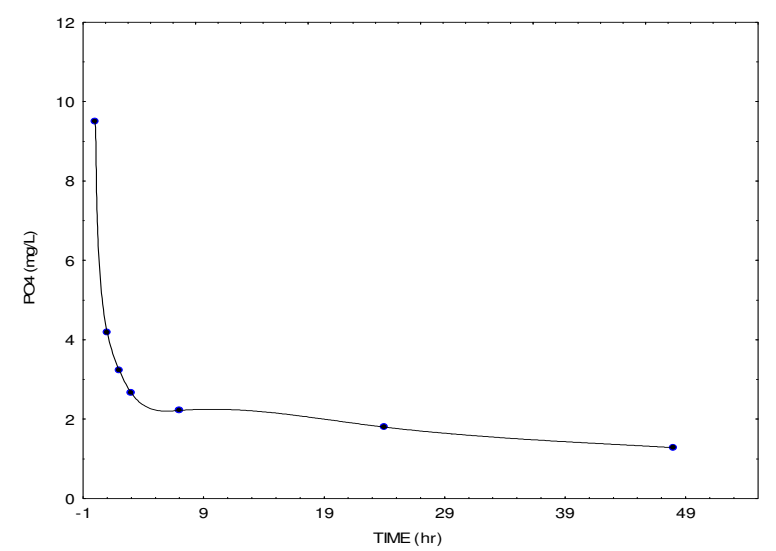

Fig. 4. $\mathrm{PO}_{4}$ Pollutant concentration with time at $\mathrm{T}=$ $2^{\circ} \mathrm{C}$, $\mathrm{pH} 7$, wastewater/(Algae broth) ratio $=1$, and sterilized wastewater.

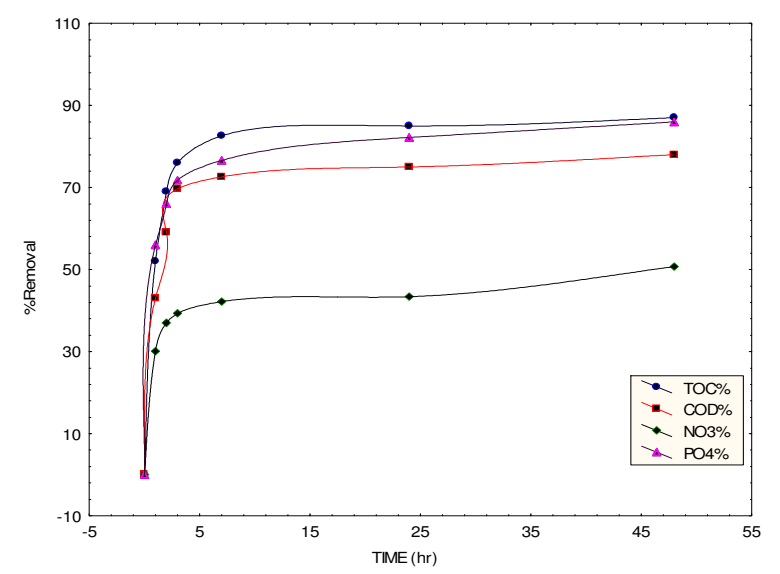

Fig. 5. Removal per cent of Pollutants with time at $\mathrm{T}=\mathbf{2 5}^{\circ} \mathrm{C}$, $\mathrm{pH}$, wastewater/(Algae broth) ratio $=1$, and sterilized wastewater. 


\subsection{Sterilization Effect}

To show the effect of microorganisms on the concentration and consumption of pollutants, the wastewater is taken directly (without sterilization) for treatment.

Figures $6-13$ show the difference between the sterilized and unsterilized wastewater on the concentration level and removal percent for each pollutants. It can be seen that the efficiency of treatment in case of unsterilized wastewater is better than sterilized wastewater but the difference is little (not more than 5\%). That means the effect of other microorganisms on the consumption of pollutant is low compare with microalgae.

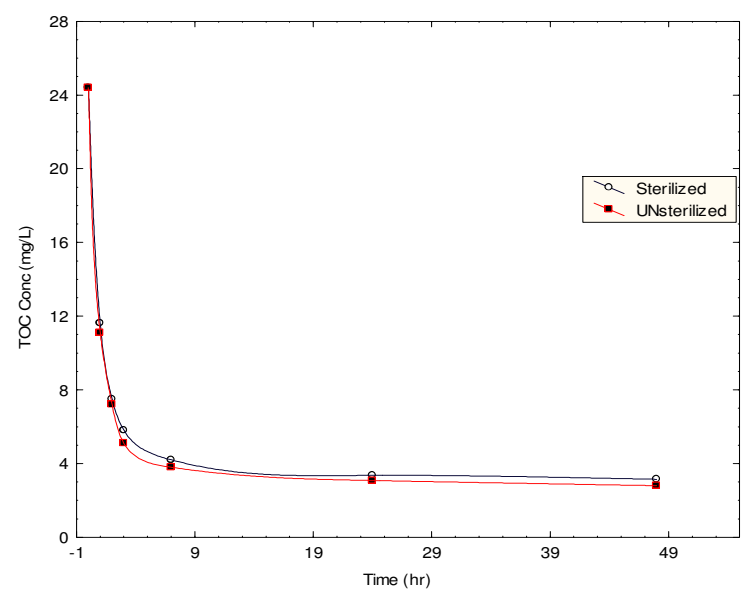

Fig. 6. Effect of sterilization on the concentration level of TOC pollutant with time at $\mathrm{T}=25^{\circ} \mathrm{C}, \mathrm{pH}$, wastewater/(Algae broth) ratio $=1$.

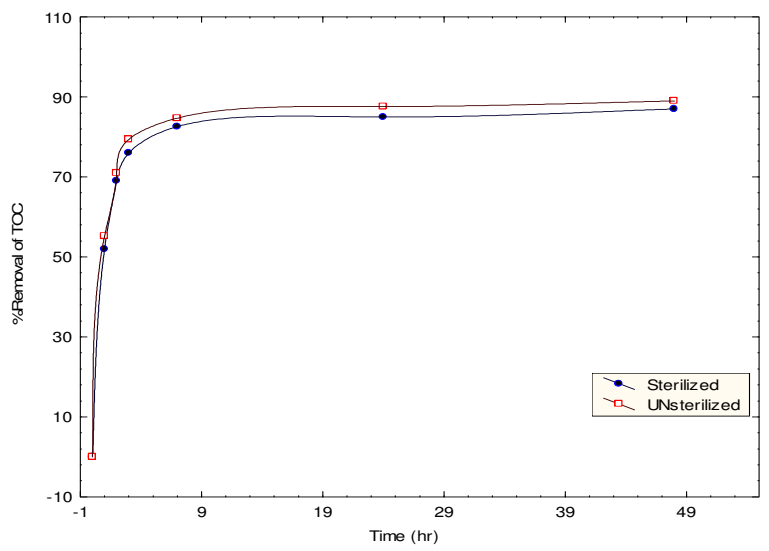

Fig. 7. Effect of sterilization on Removal percent of TOC pollutant with time at $\mathrm{T}=25^{\circ} \mathrm{C}, \mathrm{pH} 7$, wastewater/ (Algae broth) ratio $=1$.

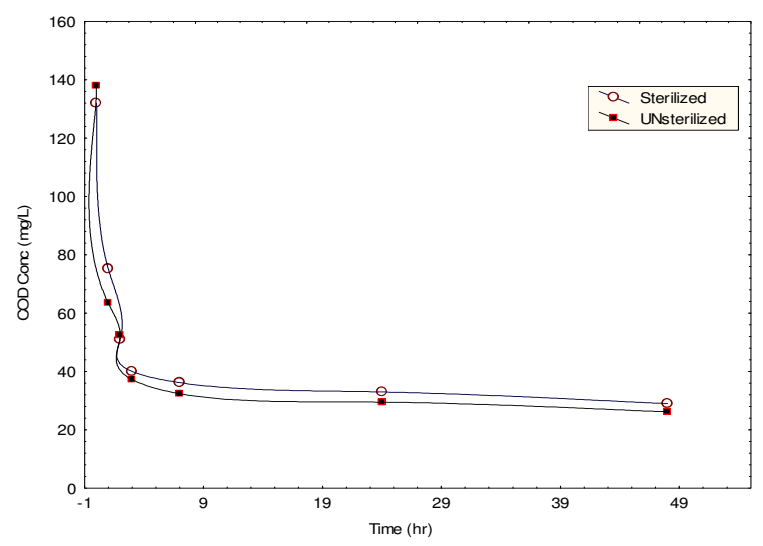

Fig. 8. Effect of sterilization on the concentration level of COD pollutant with time at $\mathrm{T}=25^{\circ} \mathrm{C}, \mathrm{pH} 7$, wastewater/(Algae broth) ratio $=1$.

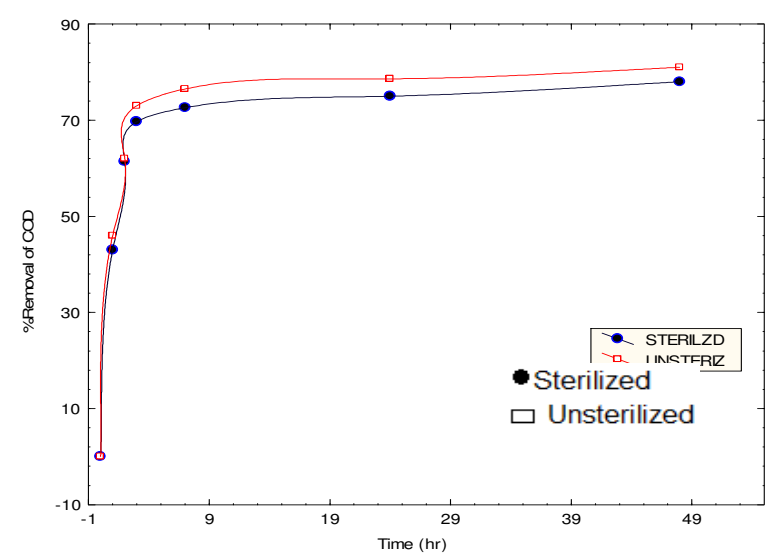

Fig. 9. Effect of sterilization on Removal percent of COD pollutant with time at $\mathrm{T}=25^{\circ} \mathrm{C}, \mathrm{pH} 7$, wastewater/(Algae broth) ratio $=1$.

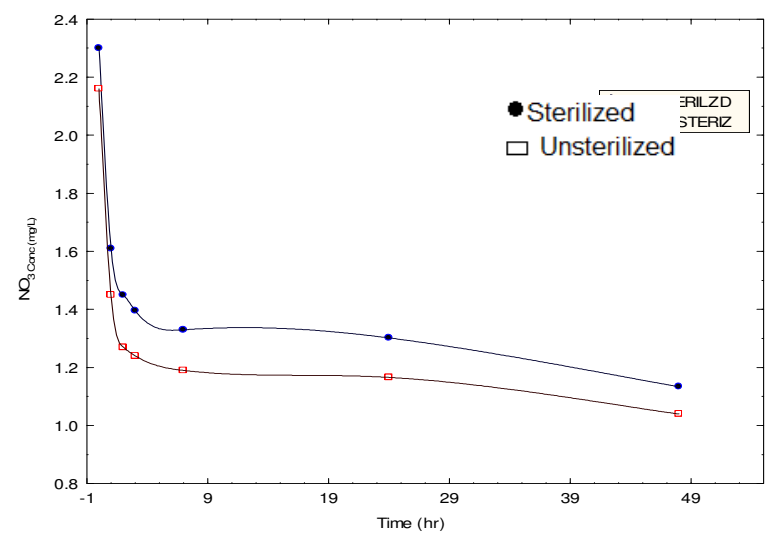

Fig. 10. Effect of sterilization on the concentration level of $\mathrm{NO}_{3}$ pollutant with time at $\mathrm{T}=25^{\circ} \mathrm{C}, \mathrm{pH} 7$, wastewater/ (Algae broth) ratio $=1$. 


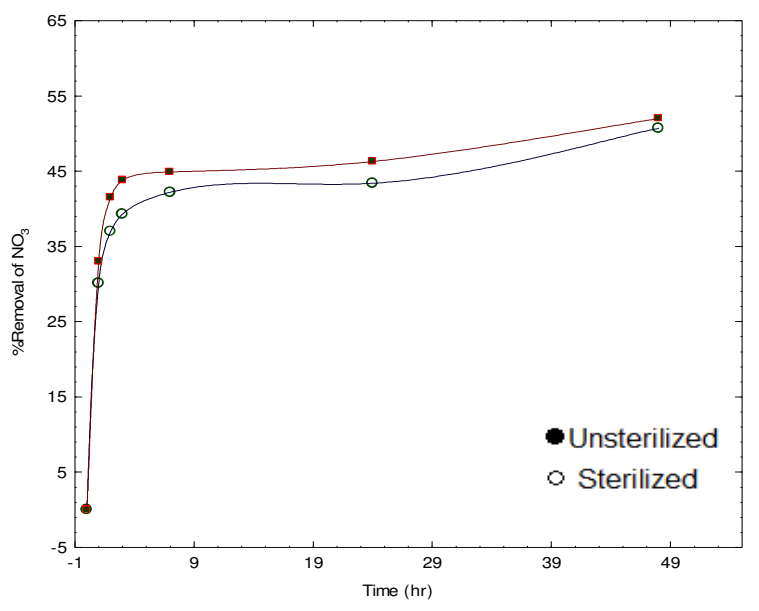

Fig. 11. Effect of sterilization on Removal percent of $\mathrm{NO}_{3}$ pollutant with time at $\mathrm{T}=2^{\circ} \mathrm{C}, \mathrm{pH} 7$, wastewater/ (Algae broth) ratio $=1$.

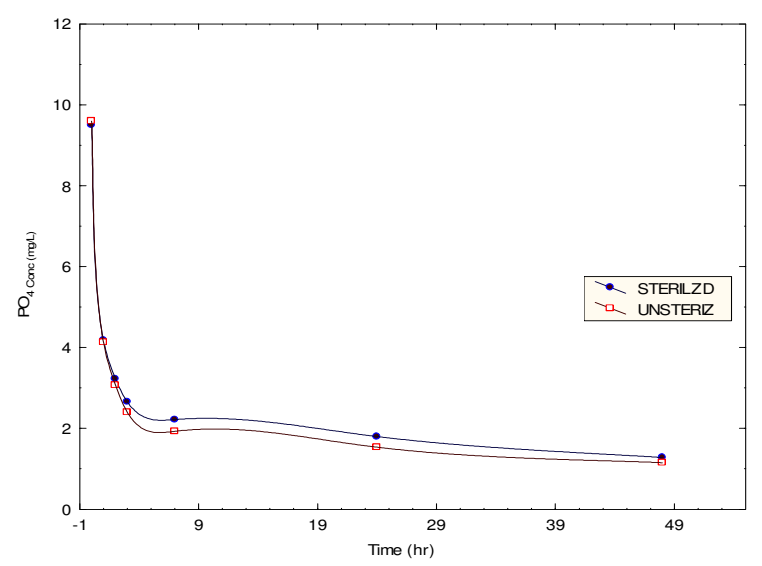

Fig. 12. Effect of sterilization on the concentration level of $\mathrm{PO}_{4}$ pollutant with time at $\mathbf{T}=25^{\circ} \mathrm{C}, \mathbf{p H} 7$, wastewater/ (Algae broth) ratio $=1$.

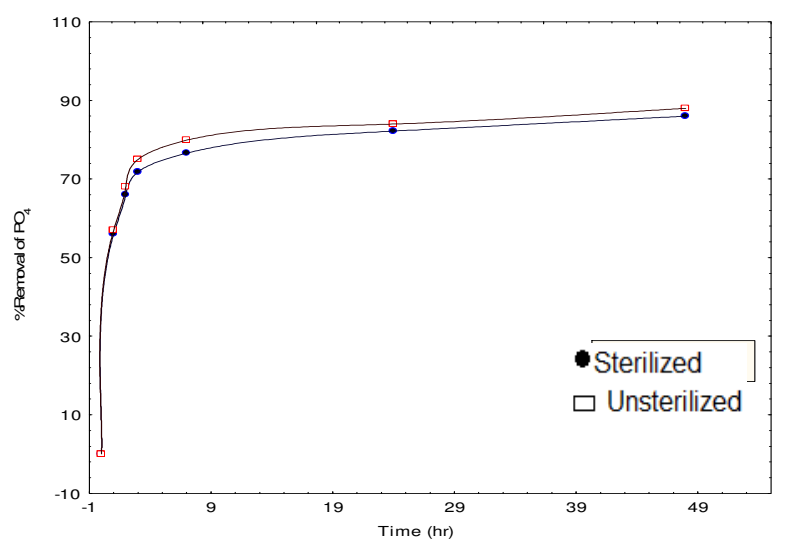

Fig. 13. Effect of sterilization Removal percent of $\mathrm{PO}_{4}$ pollutant with time at $\mathrm{T}=25^{\circ} \mathrm{C}$, pH 7 , wastewater/ (Algae broth) ratio $=1$.

\subsection{Effect of Packing Type}

The microalgae are grown on the packing and used in the treatment of pollutants. Two types of packing are used: plastic cylinder and polypropylene cubic. The amount of wastewater is still $250 \mathrm{ml}$ are added to the column of treatment then add the packing where the packing is filled the entire column and the wastewater fills the porosity of the column. Figures $14-21$ show the effect of the packing type on the concentration of pollutants and their removal percent with time. It is clear that the plastic cylinder has more efficiency on the removal of pollutants than the polystyrene cubic. The reason is the microalgae has more density on the plastic and the plastic cylinder is hollow while the polystyrene cubic is block body (without hollow), so the microalgae will grow on the outer and inner surface of plastic cylinder. Also it can be seen that from figures 1421 the broth of algae has more efficiency than the two packing. In case of broth of microalgae, the amount of microalgae can be controlled more flexible than the packing.

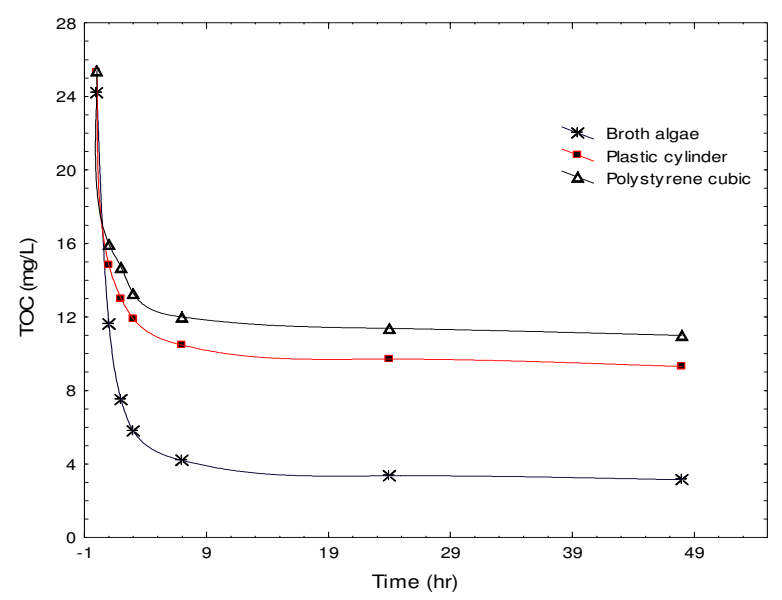

Fig. 14. Effect of Packing type on the concentration level of TOC pollutant with time at $\mathrm{T}=25^{\circ} \mathrm{C}, \mathrm{pH}$, and sterilized wastewater. 


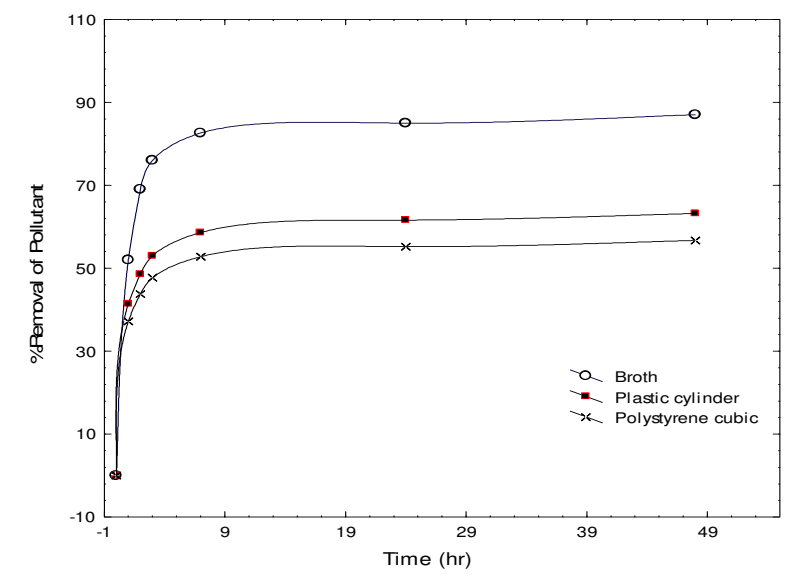

Fig. 15. Effect of Packing type on the Removal percent of TOC pollutant with time at $\mathrm{T}=25^{\circ} \mathrm{C}, \mathrm{pH}$ 7 , and sterilized wastewater.

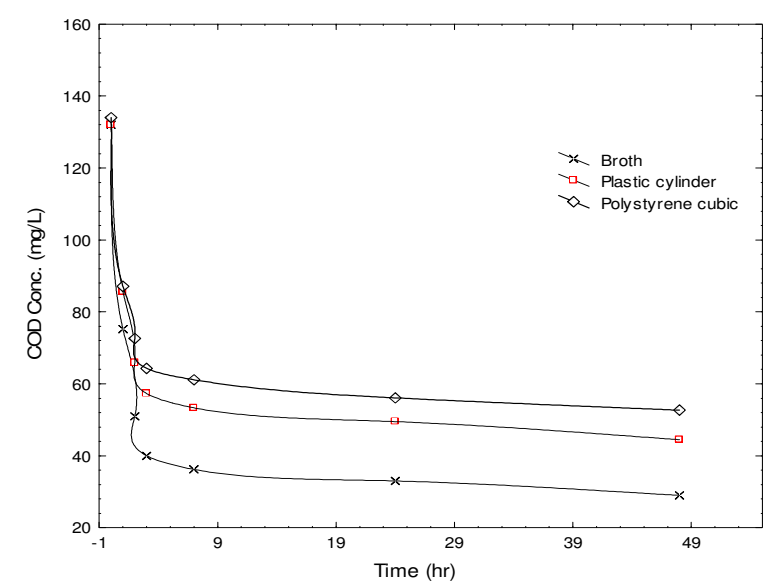

Fig. 16. Effect of Packing type on the concentration level of COD pollutant with time at $\mathrm{T}=25^{\circ} \mathrm{C}, \mathrm{pH} 7$, and sterilized wastewater.

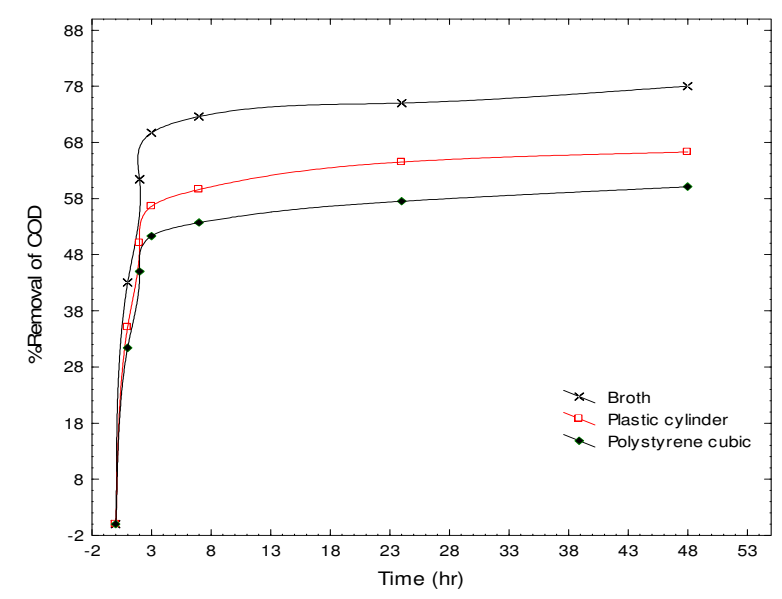

Fig. 17. Effect of Packing type on the Removal percent of COD pollutant with time at $T=25^{\circ} \mathrm{C}$, pH7, and sterilized wastewater.

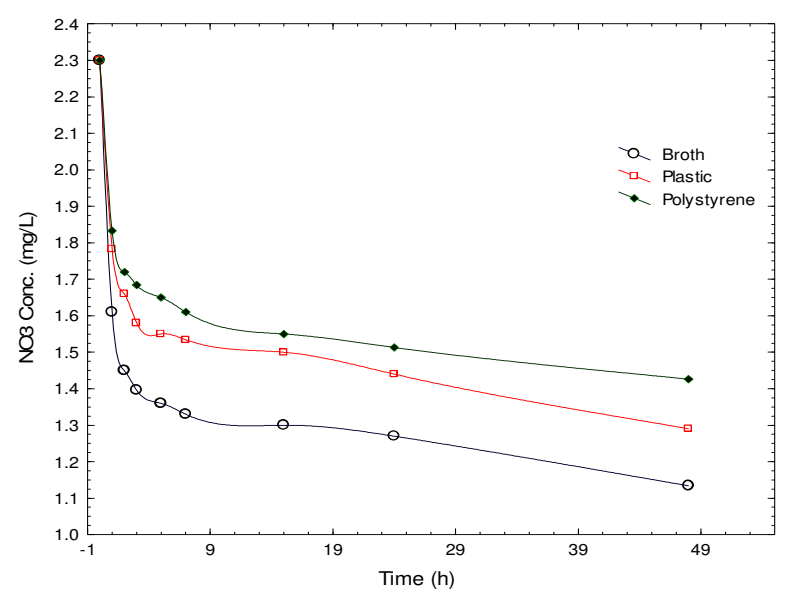

Fig. 18. Effect of Packing type on the concentration level of $\mathrm{NO}_{3}$ pollutant with time at $\mathrm{T}=25^{\circ} \mathrm{C}, \mathrm{pH} 7$, and sterilized wastewater.

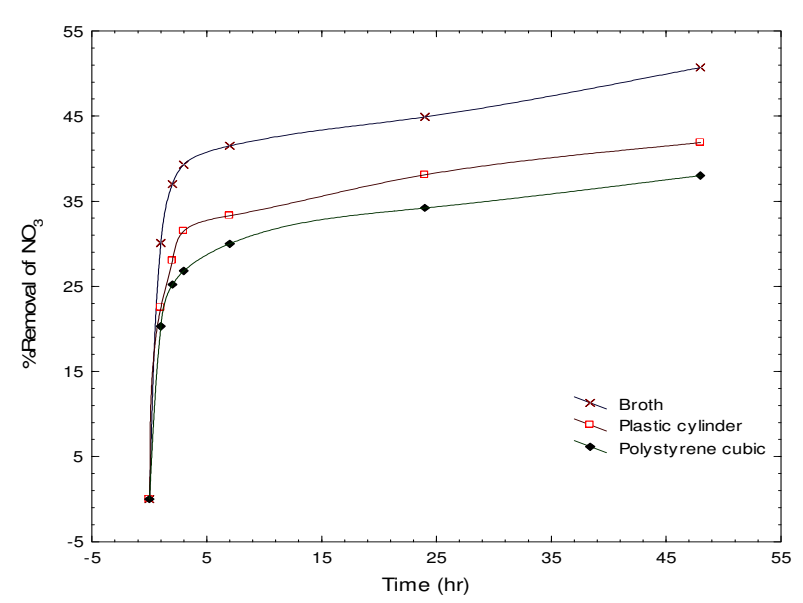

Fig. 19. Effect of Packing type on the Removal per cent of $\mathrm{NO}_{3}$ pollutant with time at $\mathrm{T}=25^{\circ} \mathrm{C}, \mathrm{pH} 7$, and sterilized wastewater.

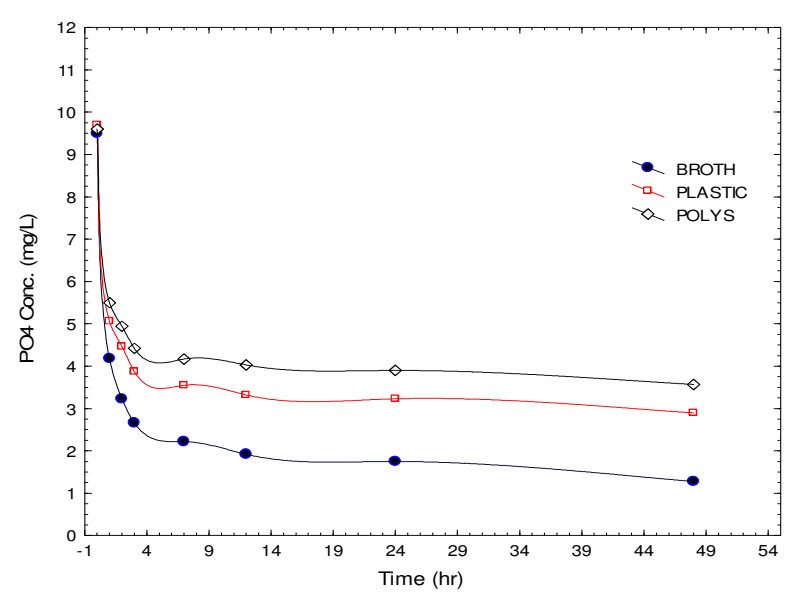

Fig. 20. Effect of Packing type on the concentration level of $\mathrm{PO}_{4}$ pollutant with time at $\mathrm{T}=25^{\circ} \mathrm{C}, \mathrm{pH} 7$, and sterilized wastewater. 


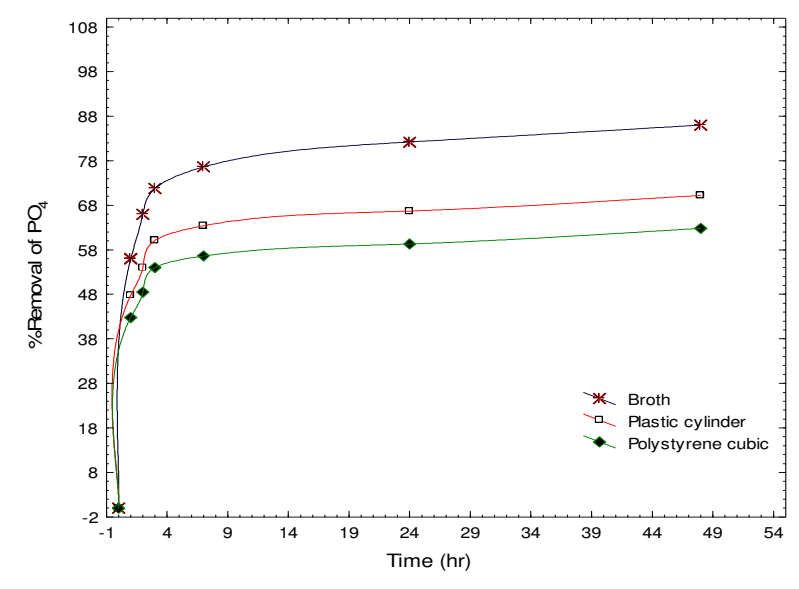

Fig. 21. Effect of Packing type on the Removal percent of $\mathrm{PO}_{4}$ pollutant with time at $\mathrm{T}=25^{\circ} \mathrm{C}, \mathrm{pH}$, wastewater/ (Algae packing) ratio $=1$, and sterilized wastewater.

\subsection{Other Parameters Effect}

The other parameters which are studied in reduction of pollutants are:

Temperature: $20-35^{\circ} \mathrm{C}, \quad \mathrm{pH}: \quad 5-8$, and Wastewater/ (Algae broth) volume ratio (1.02.5).

Design of experiments are achieved by Taguchi method in MiniTab software statistics. Table 2 shows the number of the experiments with their parameters.

According to the results of experiments in the figures $(1-21)$ the microalgae broth, time of treatment $(48 \mathrm{hr})$ and sterilized wastewater will used in the next experiments. Here the sterilized wastewater is dependent in this study although the unsterilized is more effective because in the next section will study the adsorption isotherm of microalgae to the pollutants.
Table 2,

levels of the parameters studied that divided by statistical program.

\begin{tabular}{llll}
\hline Run No. & Temp $^{\mathbf{0}} \mathbf{C}$ & $\mathbf{p H}$ & $\begin{array}{l}\text { wastewater } \\
\text { algae broth }\end{array}$ \\
\hline 1 & 20 & 5 & 1 \\
2 & 20 & 6 & 1.5 \\
3 & 20 & 7 & 2 \\
4 & 20 & 8 & 2.5 \\
5 & 25 & 5 & 1.5 \\
6 & 25 & 6 & 1 \\
7 & 25 & 7 & 2.5 \\
8 & 25 & 8 & 2 \\
9 & 30 & 5 & 2 \\
10 & 30 & 6 & 2.5 \\
11 & 30 & 7 & 1 \\
12 & 30 & 8 & 1.5 \\
13 & 35 & 5 & 2.5 \\
14 & 35 & 6 & 2 \\
15 & 35 & 7 & 1.5 \\
16 & 35 & 8 & 1 \\
\hline
\end{tabular}

Table 3 shows the results of the pollutants concentration and their removal per cent according to the parameters of table 2 . 
Table 3,

Effect of parameters of table 2 on the concentration of pollutants and their removal per cent for sterilized wastewater using broth of microalgae and treatment time of 48 hours.

\begin{tabular}{lllllllll}
\hline Run No. & $\begin{array}{l}\text { TOC } \\
\text { Conc. } \mathbf{m g} / \mathbf{L}\end{array}$ & $\begin{array}{l}\text { TOC } \\
\text { removal } \\
\text { \% }\end{array}$ & $\begin{array}{l}\text { COD } \\
\text { Conc.mm } \\
\text { g/L }\end{array}$ & $\begin{array}{l}\text { COD } \\
\text { removal\% }\end{array}$ & $\begin{array}{l}\mathbf{N O}_{3} \\
\text { Conc.mm } \\
\text { g/L }\end{array}$ & $\begin{array}{l}\mathbf{N O}_{3} \\
\text { removal } \\
\text { \% }\end{array}$ & $\begin{array}{l}\text { PO4 }_{4} \\
\text { Conc.mm } \\
\text { g/L }\end{array}$ & $\begin{array}{l}\text { PO4 } \\
\text { removal\% }\end{array}$ \\
\hline Control & 24.4 & 0 & 132 & 0 & 2.3 & 0 & 9.84 & 0 \\
1 & 4.587 & 81.2 & 29.96 & 77.3 & 1.104 & 52.0 & 1.673 & 83.0 \\
2 & 6.32 & 74.1 & 35.25 & 73.3 & 1.134 & 50.7 & 2.135 & 78.3 \\
3 & 8.2 & 66.4 & 50.16 & 62.0 & 1.214 & 47.2 & 3.464 & 64.8 \\
4 & 10.42 & 57.3 & 61.78 & 53.2 & 1.35 & 41.3 & 3.87 & 60.7 \\
5 & 5.5 & 77.5 & 31.95 & 75.8 & 1.143 & 50.3 & 1.93 & 80.4 \\
6 & 3.074 & 87.4 & 30.1 & 77.2 & 1.093 & 52.5 & 1.28 & 87.0 \\
7 & 9.03 & 63.0 & 59.4 & 55.0 & 1.334 & 42.0 & 3.64 & 63.0 \\
8 & 7.174 & 70.6 & 50.95 & 61.4 & 1.196 & 48.0 & 3.0 & 69.5 \\
9 & 7.64 & 68.7 & 43.03 & 67.4 & 1.249 & 45.7 & 3.23 & 67.2 \\
10 & 8.5 & 65.2 & 45.28 & 65.7 & 1.297 & 43.6 & 3.287 & 66.6 \\
11 & 1.9 & 92.2 & 19.0 & 85.6 & 1.0 & 56.2 & 0.777 & 92.1 \\
12 & 4.78 & 80.4 & 29.7 & 77.5 & 4.09 & 51.0 & 2.627 & 73.3 \\
13 & 9.0 & 63.1 & 51.48 & 61.0 & 1.279 & 44.4 & 3.62 & 63.2 \\
14 & 5.25 & 78.5 & 38.15 & 71.1 & 1.189 & 48.3 & 3.01 & 69.4 \\
15 & 2.14 & 91.2 & 20.6 & 84.4 & 0.888 & 61.4 & 1.181 & 88.0 \\
16 & 1.88 & 92.3 & 19.54 & 85.2 & 0.8 & 65.2 & 0.67 & 93.2 \\
\hline
\end{tabular}

It can be seen from table 3 that the maximum \%removal of pollutants $\mathrm{TOC}=92.3 \%, \mathrm{NO}_{3}=$ $65.2 \%$, and $\mathrm{PO}_{4}=93.2 \%$ all at experiment number $16\left(\mathrm{~T}=35^{\circ} \mathrm{C}, \quad \mathrm{pH} \quad 8\right.$, and (wastewater/algae broth) ratio $=1$ ) while the $\%$ removal of pollutant $\mathrm{COD}=85.6 \%$ at experiment $11\left(\mathrm{~T}=30^{\circ} \mathrm{C}, \mathrm{pH} \quad 7\right.$, and (wastewater/algae broth) ratio $=1$ ).

The \%removal of the pollutants above may be greater by about $5 \%$ if the unsterilized wastewater is used.

From table 3 it is clear that the ratio of wastewater/algae broth has greater effect on the reduction of pollutants compare with the temperature and $\mathrm{pH}$.

In general, the reduction of pollutants is increased with increasing of temperature, neutral of $\mathrm{pH}$ and decrease of wastewater/algae ratio.

\section{Statistical Analysis}

By statistical analysis, table 4 shows the coefficients for each predicted equation of the pollutants removal per cent.

Table 4,

Coefficients for each equation of the predicted value for pollutants removal per cent.

\begin{tabular}{|c|c|c|c|c|}
\hline \multicolumn{5}{|c|}{$\begin{array}{l}\text { Pollutant }=\text { bo+b1 } * \mathbf{T}+\mathrm{b} 2 * \mathrm{pH}+\mathrm{b3} * \mathrm{r}+\mathrm{b} 4 * \mathrm{~T} * \mathrm{pH}+\mathrm{b5} * \mathrm{~T} * \mathbf{r}+\mathrm{b} 6 * \mathrm{pH} * \mathrm{r}+\mathrm{b} 7 * \mathrm{~T} * \mathrm{pH} * \mathrm{r} \\
\mathrm{T}=\text { Temperature, } \mathrm{r}=\text { wastewater/(Algae broth) ratio }\end{array}$} \\
\hline Coefficient & TOC & COD & $\mathrm{NO}_{3}$ & $\mathrm{PO}_{4}$ \\
\hline \multirow{8}{*}{$\begin{array}{l}\text { bo } \\
\text { b1 } \\
\text { b2 } \\
\text { b3 } \\
\text { b4 } \\
\text { b5 } \\
\text { b6 } \\
\text { b7 }\end{array}$} & 2.33194 & 28.80407 & 104.6561 & 109.6277 \\
\hline & 4.96731 & 2.61733 & -1.8757 & 0.4482 \\
\hline & 11.06484 & 5.80584 & -11.2473 & -7.8307 \\
\hline & 30.29022 & 44.49052 & -14.9886 & -6.5373 \\
\hline & -0.58434 & -0.24116 & 0.4613 & 0.1807 \\
\hline & -2.49989 & -2.11445 & 0.4295 & -0.5944 \\
\hline & -6.93836 & -8.02477 & 2.9692 & 1.2390 \\
\hline & 0.37222 & 0.29222 & -0.1311 & -0.0078 \\
\hline$\%$ Error from actual & $\mathrm{R}^{2}=0.991$ & $\mathrm{R}^{2}=0.973$ & $\mathrm{R}^{2}=0.953$ & $\mathrm{R}^{2}=0.96$ \\
\hline
\end{tabular}


From table 4, It can be seen that the parameter has more effect on the treatment is (wastewater/ (Algae broth) ratio, while the other parameters have less effect in their range.

\section{Adsorption Isotherm}

The type of the adsorption for pollutants on the organic microalgae are analyzed using three types of adsorption isotherms [13, 14, 15]:

- Linear Isotherm: $C_{S}=K C$

- Freundlich Isotherm: $C_{S}=K_{F} C^{1 / n}$

- Langmuir Isotherm: $C_{S}=\frac{C_{S \max } C}{K_{L}+C}$

Where:

$C_{S}=$ equilibrium solute concentration per unit amount of adsorbent ( $\mathrm{kg}$ solute $/ \mathrm{m}^{3}$ solid)

$C=$ equilibrium solute concentration in solution $\left(\mathrm{kg} / \mathrm{m}^{3}\right)$

$K=$ linear equilibrium constant (-)

$K_{F}=$ Freundlich adsorption constant

The dimensions of $K_{F}$ depend on the dimensions

of $C_{S}$ and $C$ and the value of $\mathrm{n}$.

$K_{L}=$ Langmuir adsorption constant, it has the

same dimensions of $C$.
$C_{S \operatorname{smax}}=$ maximum concentration of solute (pollutant) on the solid (microalgae)

The equilibrium data of $C_{S}$ and $C$ that occur during the experiment will follow any of the adsorption isotherms above when the relation between $C_{S}$ and $C$ is linear as shown in the checking below:

For check the linearity a linear adsorption isotherm $C_{s}$ is plot against $C$ (Eq. 1), for Freundlich adsorption isotherm, using linear form of Eq. $2\left(\log C_{S}=\log K_{F}+\frac{1}{n} \log C\right) \log C_{s}$ is plot against $\log C$ and for Langmuir adsorption isotherm also using linear form of Eq.3 ( $\frac{1}{C_{S}}=$ $\left.\frac{K_{L}}{C_{S \max C}}+\frac{1}{C_{S \max }}\right) 1 / C_{s}$ is plot against $1 / C$ (Eq. 3).

It is taken $1-4$ experiments of the table 3 when the wastewater/ (algae broth) ratio change from 1 - 2.5. Table 5 shows the equilibrium concentrations of pollutants in the wastewater $(C)$ and on the algae $\left(C_{S}\right)$. The cell density of Chlorrela vulgaris was determined by measuring the optical density of a $10-\mathrm{mL}$ sample at $682 \mathrm{~nm}$ by using UV-vis spectrophotometer (UV 1800, Shimadzu Scientific Instruments)

Table 5,

Equilibrium concentrations in the wastewater and on the microalgae for pollutants.

\begin{tabular}{|c|c|c|c|c|c|c|c|c|c|}
\hline Run & Dry weight & TOC & & COD & & $\mathrm{NO}_{3}$ & & $\mathrm{PO}_{4}$ & \\
\hline No. & of algae $\mathrm{g}$ & $C m g / L$ & $C_{S} m g / g$ & $C m g / L$ & $C_{S} m g / g$ & $C m g / L$ & $C_{S} m g / g$ & $C m g / L$ & $C_{S} m g / g$ \\
\hline 1 & 2.3 & 4.587 & 8.614 & 29.96 & 44.36 & 1.104 & 0.52 & 1.673 & 3.55 \\
\hline 2 & 1.53 & 6.32 & 11.817 & 35.25 & 63.24 & 1.134 & 0.762 & 2.135 & 5.036 \\
\hline 3 & 1.15 & 8.2 & 14.087 & 50.16 & 71.17 & 1.214 & 0.944 & 3.464 & 5.544 \\
\hline 4 & 0.92 & 10.42 & 15.2 & 61.78 & 76.33 & 1.35 & 1.032 & 3.87 & 6.49 \\
\hline
\end{tabular}

Figures (22-24) show the relation between $C_{S}$ and $C$ for the pollutant TOC.

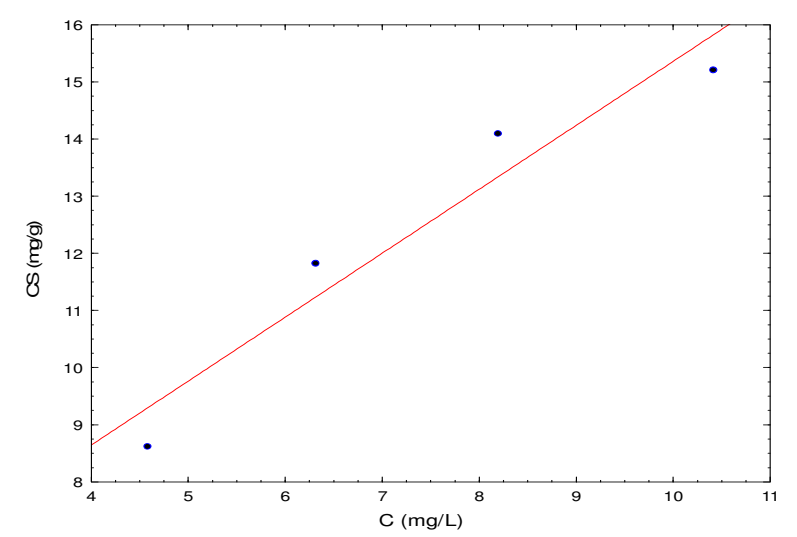

Fig. 22. Plot the concentrations according to linear adsorption isotherm for TOC.

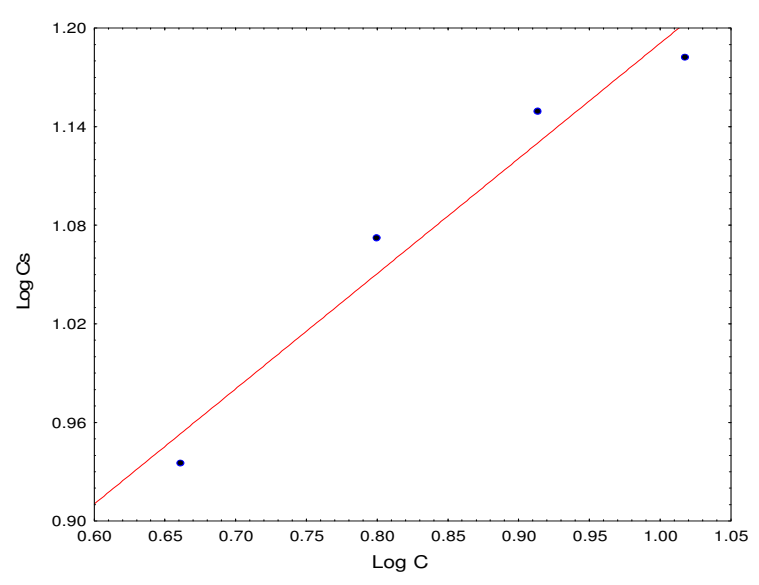

Fig. 23. Plot the concentrations according to Freundlich adsorption isotherm for TOC. 


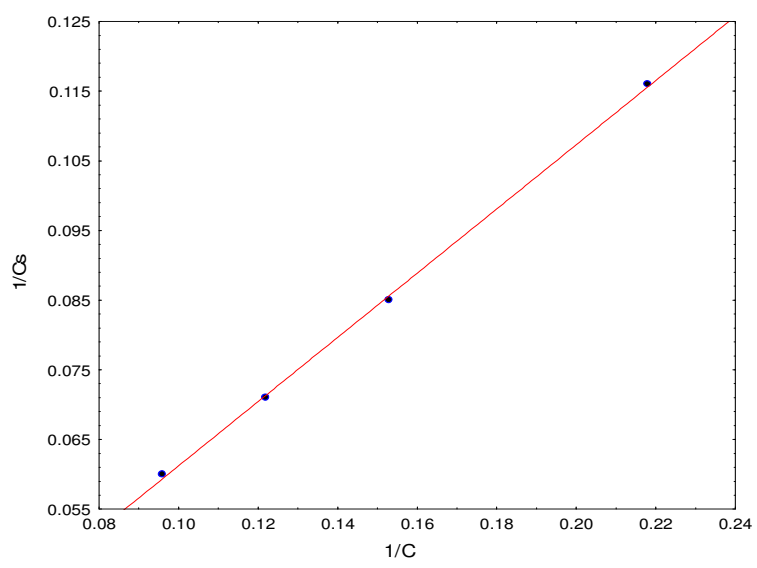

Fig. 24. plot the concentrations according to Langmuir adsorption isotherm for TOC.

It is clear that from figure 24 the data concentration of TOC are agreement with Langmuir adsorption isotherm compare with figure 22 (Linear isotherm) and figure 23 (Freundlich isotherm).

By the same way, it can be test the adsorption isotherm for the other pollutants and found that they are also agreement with Langmuir adsorption isotherm as shown in the figures $25-27$ for COD, $\mathrm{NO}_{3}$ and $\mathrm{PO}_{4}$ respectively.

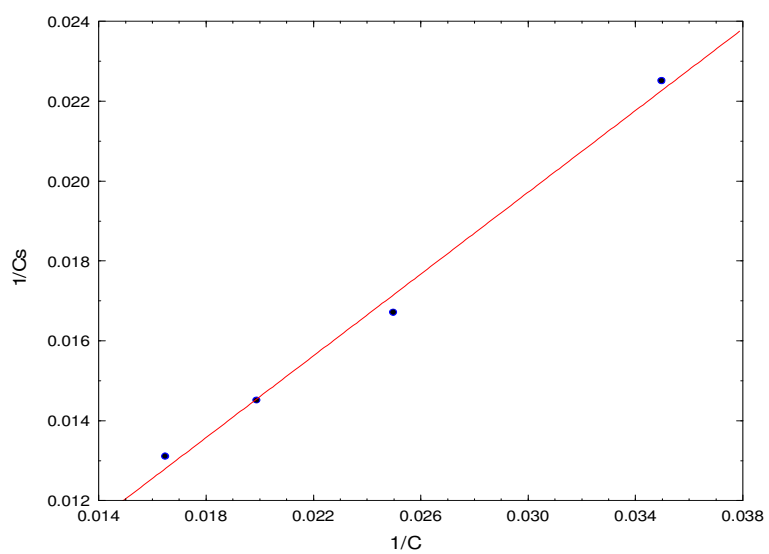

Fig. 25. Plot the concentrations according to Langmuir adsorption isotherm for COD.

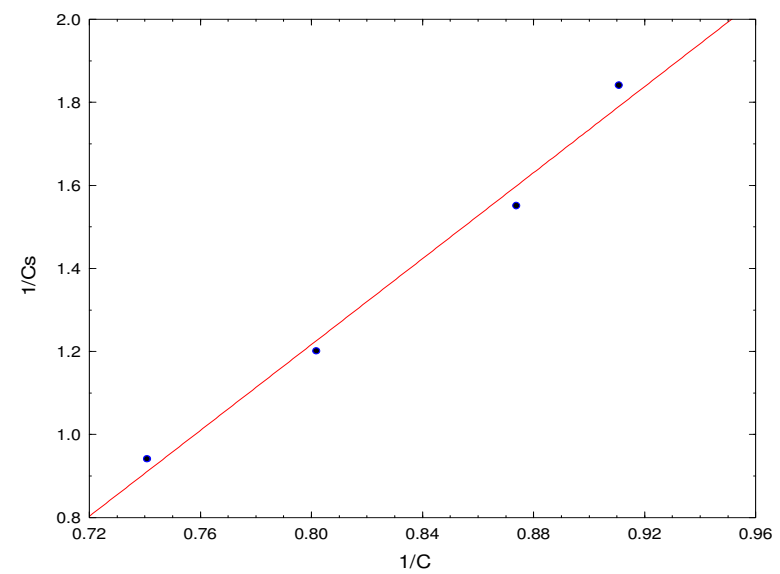

Fig. 26. plot the concentrations according to Langmuir adsorption isotherm for $\mathrm{NO}_{3}$.

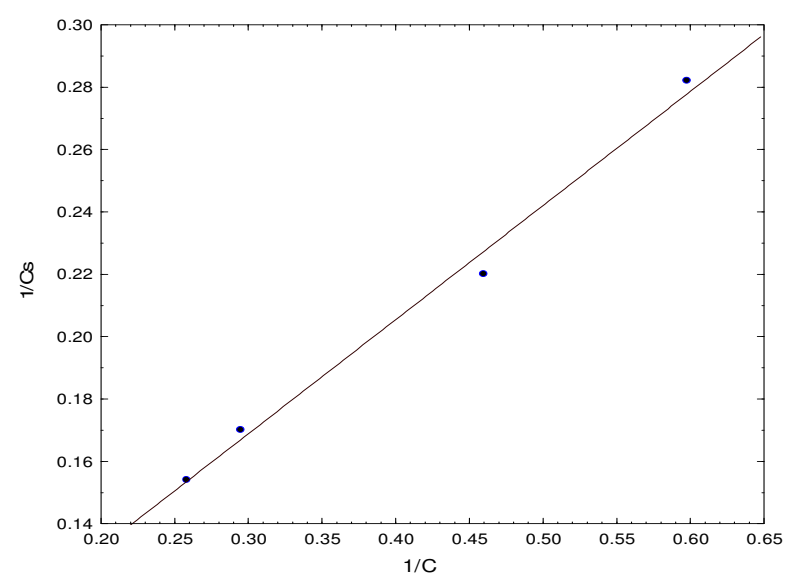

Fig. 27. Plot the concentrations according to Langmuir adsorption isotherm for $\mathrm{PO}_{4}$.

From figures 24 the constants of the Langmuir Isotherm $\left(C_{\operatorname{Smax}}\right.$ and $\left.K_{L}\right)$ for all pollutants are estimated and shown in table 6:

From equation 3;

$\frac{1}{C_{S}}=\frac{K_{L}}{C_{S \max C}}+\frac{1}{C_{S \max }}$

Where the $K_{L} / C_{S \max }$ is the slope and $1 / C_{S \max }$ is the intercept of the figure 24 and other figures that are drawn according to the Langmuir Isotherm.

Table 6,

Constants of Langmuir isotherm for all treated pollutants.

\begin{tabular}{lllll}
\hline Constants & TOC & COD & NO3 $_{3}$ & PO $_{4}$ \\
\hline$C_{S \max } \mathrm{mg} / \mathrm{g}$ & 47.62 & 232.56 & 1.742 & 15.38 \\
$K_{L} \mathrm{mg} / \mathrm{L}$ & 19.63 & 127.33 & 10.05 & 5.71 \\
\hline
\end{tabular}




\section{Conclusions}

1. The reduction of pollutants in unsterilized wastewater is more effective than the sterilized wastewater.

2. For the sterilized wastewater the maximum removal of the pollutants that achieved after 48 hr are: $\mathrm{TOC}=92.3 \%, \mathrm{COD}=85.6 \%, \mathrm{NO} 3=$ $65.2 \%$, and $\mathrm{PO} 4=93.2 \%$ and can be obtain more reduction by about $5 \%$ if the unsterilized wastewater is used.

3. The reduction of pollutants is very fast in first hours of treatment and progressively slows down.

4. Broth of microalgae (without packing) has more efficiency than the microalgae that grown on the packing and the packing of cylindrical plastic has more efficiency than the cubic polystyrene.

5. The temperature and $\mathrm{pH}$ have little effect on the reduction of pollutants, while the volume ratio of wastewater/algae broth has the great effective on the treatment.

6. The adsorption of all pollutants that treated (TOC, COD, NO3, and PO4) are followed the Langmuir isotherm.

\section{References}

[1] A. Saad Al-Jlil, COD and BOD Reduction of Domestic Wastewater using Activated Sludge, Sand Filters and Activated Carbon in Saudi Arabia, Biotechnology Volume 8 (4): 473-477, 2009.

[2] Satpal and A. K. Khambete, Waste Water Treatment Using Micro-Algae - A review Paper, International Journal of Engineering Technology, Management and Applied Sciences Volume 4, Issue 2, 2016.

[3] F. L. Sérgio Pereira, L. Ana Gonçalves, C. Francisca Moreira, F. C. V. Tânia Silva, J. P. Vítor Vilar and C. M. José Pires, "Nitrogen Removal from Landfill Leachate by Microalgae", November 2016.

[4] M.H. Sayadi , N. Ahmadpour, M. Fallahi Capoorchali, M.R. Rezaei, Removal of nitrate and phosphate from aqueous solutions by microalgae: An experimental study, Global J. Environ. Sci. Manage., 2(3): 357364, 2016.

[5] Hee-Jeong Choi and Seung-Mok Lee, "Effects of Microalgae on the Removal of
Nutrients from Wastewater: Various Concentrations of Chlorella vulgaris", Environ. Eng. Res. December,17(S1) 2012.

[6] Florian Delrue, Pablo David Álvarez-Díaz, Sophie Fon-Sing, Gatien Fleury, and JeanFrançois Sassi, "The Environmental Biorefinery: Using Microalgae to Remediate Wastewater, a Win-Win Paradigm" 25 February 2016.

[7] J. Pittman, A. Dean, O. Osundeko., The potential of sustainable algal biofuel production using wastewater resources. Bioresource Technology. 102:17-25, 2011.

[8] J. Benemann, J. Weissman, B. Koopman, W. Oswald. Energy production by microbial photosynthesis. Nature. 268:19-23, 1977.

[9] T. Mata, A. Martins, N. Caetano. Microalgae for biodiesel production and other applications: A review. Renewable and Sustainable Energy Reviews. 14:217-232, 2010.

[10] I. Rawat, R. Ranjith Kumar, T. Mutanda, F. Bux. Dual role of microalgae: Phycoremediation of domestic wastewater and biomass production for sustainable biofuels production. Applied Energy. 88:3411 -3424, 2011.

[11] S. Chalvindera, Bioremedation of wastewater using microalgae, 1689-1699, 2014.

[12] M. ATTA, A. Idris, A. Bukhari, and S. Wahidin, Intensity of blue LED light: a potential stimulus for biomass and lipid content in fresh water microalgae Chlorella vulgaris. Bioresource technology, 148, 373378, 2013.

[13] J. M. Coulson and J. F. Richardson Chemical Engineering Vol. 2 Particle Technology and Separation Process, 5ed 2002, Ch. 17.

[14] J. D. Seader, J. Ernest Henley, D. Keith Roper "Separation Process Principles Chemical and Biochemical Operations" 3rd ed. John Wiley \& Sons, Inc. 2011, Ch. 15.

[15] Meroufel, B. O. Benali, M. Benyahia,Y. Benmoussa, M.A. Zenasni, Adsorptive removal of anionic dye from aqueous solutions by Algerian kaolin: Characteristics, isotherm, kinetic and thermodynamic studies, J. Mater. Environ. Sci. 4 (3) 482-491, 2013. 


\title{
خفض الملوثات من مياه فضلات البلاية بأستخدام الطحالب المجهرية Chlorella vulgaris
}

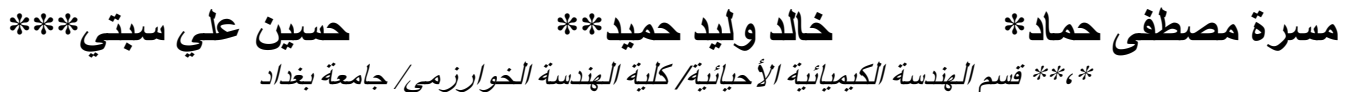

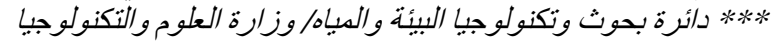

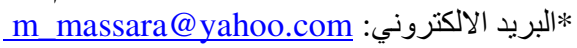

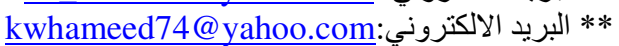 \\ sabtie_59@yahoo.com:البريد الالكتروني:2**
}

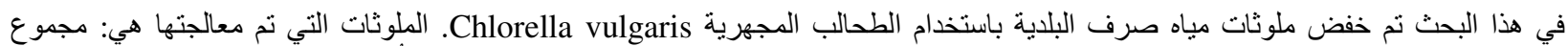

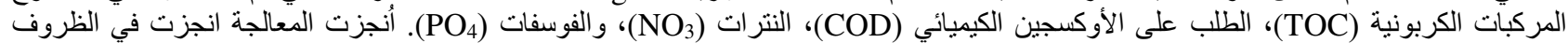

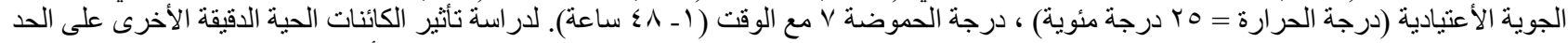

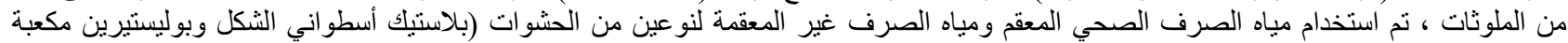

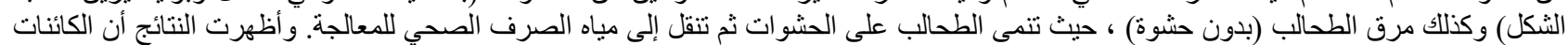

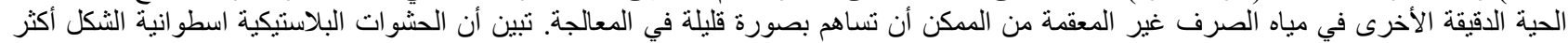

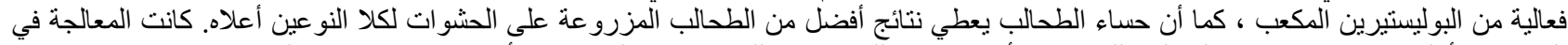

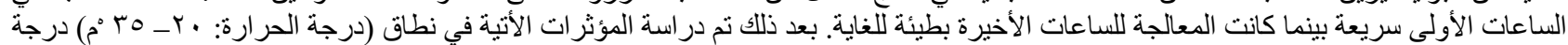

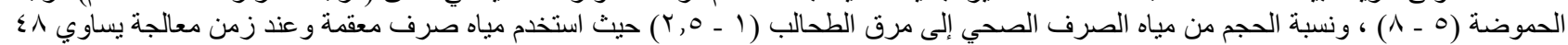

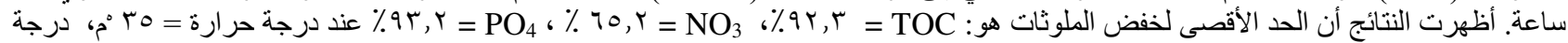

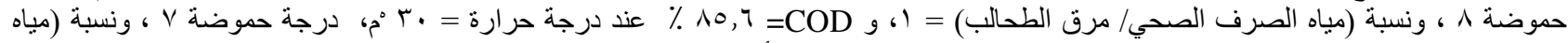

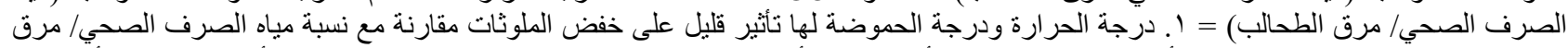

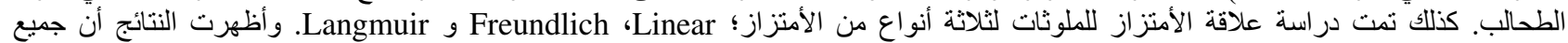

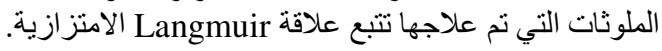

